\title{
ERPP special section editorial perspectives: COVID-19 and educational change
}

\author{
Pak Tee $\mathrm{Ng}^{1}$
}

Received: 9 September 2020 / Accepted: 30 September 2020 / Published online: 27 October 2020

(c) Springer Nature Singapore Pte Ltd. 2020

Without a doubt, COVID-19 has disrupted many education systems around the world. There are many discussions and indeed arguments about issues raised by the pandemic. Some are focused on whether schools are safe for reopening. Others are focused on whether enough resources have been allocated to schools to make them safe for children upon reopening. Yet, others are focused on whether grades for students in the various subjects, in the absence of a national examination, are fair or otherwise. These are very difficult and practical matters. The pandemic has triggered a few of us (Andy Hargreaves, Pasi Sahlberg and Pak Tee Ng) to reflect on educational change. Our papers discuss the issues we reflected on.

I would like to thank the ERPP Executive Editors for commissioning this Special Section of Perspectives: COVID-19 and Educational Change within an ERPP issue, a timely initiative in view of the COVID-19 pandemic. I would like to thank Andy Hargreaves and Pasi Sahlberg, who are renowned global thought leaders in educational change, for joining me in this special section.

In his paper, Andy Hargreaves points out that after the pandemic, instead of choosing a path of austerity in education that leads to more inequality, countries should embrace an economic expansion in public education investment that pursues prosperity and leads to better outcomes for every child. Instead of a digital divide, such an approach creates the possibility of a digital dividend. Digital technology for learning should be made available as a public, universal and human right. He warns that we must remain vigilant against the erosion of the public education system by disinvestment and privatization.

Pasi Sahlberg, in his paper, emphasizes the importance of equity in education in the postCOVID-19 world. He argues, by contrasting the approaches of Australia and Finland during the pandemic, that it is paramount to make education more inclusive, fairer and equitable for all. He concludes that the pandemic may help make education more equitable if countries address current socioeconomic inequalities early; trust teachers and principals more to lead schools forward in the post-pandemic world; and support schools and children to become more self-directed in leading and learning.

I reflect on the importance of "timely change, timeless constants" as we approach educational change in Singapore triggered by the pandemic. In particular, the move toward a blended learning approach is to help students develop the capacity for independent learning, not just to replicate classroom teaching on an online platform. Also, while adapting

Pak Tee Ng

paktee.ng@nie.edu.sg

1 National Institute of Education, Nanyang Technological University, Singapore, Singapore 
very quickly to COVID-19, Singapore should continue to develop its education system in a balanced, thoughtful and steady manner, reaffirming the critical roles that school leaders, teachers and schools play in the society.

While each of us focuses on different aspects of educational change and geographical locations, a few messages are common. Investment in education matters. Equity in education matters. Schools and teachers matter. Pedagogy, not just technology, matters. While these are our personal perspectives, hopefully, they will serve as useful input into your own reflection, strategic planning or decision-making regarding educational change in your context.

Publisher's note Springer Nature remains neutral with regard to jurisdictional claims in published maps and institutional affiliations. 